\title{
Sağlık Sektöründe Bireylerin Hizmet Sunucu Tercihlerini Etkileyen Faktörler
}

\author{
Birol Yetima, b, Yusuf Çelikc
}

Özet

Sağlık sektöründe hizmet sunucu seçimi, alternatif hizmet sunucuları arasından birinin hasta veya yakınları tarafından tercih edilmesidir. Ancak sağlık hizmetlerinin karmaşık doğası nedeniyle sunucular arasında tercih yapabilmek çoğu zaman kolay değildir. Bu nedenle bu çalışmada, bireylerin sağlık hizmeti için tercih ettikleri hizmet sunucularının ve sunucu tercihlerinde etkili olan faktörlerin belirlenmesi amaçlanmıştır. Çalışmanın amaçlarına ulaşabilmek için ise TÜİK tarafından 2016 yılında yapılan Yaşam Memnuniyeti Araştırması veri seti kullanılmıştır. Bu çalışmada, bireylerin sağlık hizmeti sunucusu tercihleri kamu-özel sağlık kuruluşları ve hastaneler düzeyinde ayrı ayrı incelenmiştir. Araştırma sonucunda devlet hastanelerinin daha çok tercih edildiği ve bireylerin bu tercihlerinde bireysel ve demografik özelliklerinin yanı sıra sağlık hizmetlerinden memnuniyet ya da hizmet sunucunusun yakınlığı gibi diğer faktörlerin etkili olduğu tespit edilmiştir. Bu çalışmanın sağlık yöneticilerine kanıta dayalı bilgiler sunacağı düşünülmektedir.

\section{Anahtar Kelimeler}

Sağlık Hizmet Sunucusu

Hastane Seçimi

Hasta Memnuniyeti

TÜİK

\section{Makale Hakkında}

Geliş Tarihi: 31.01.2020

Kabul Tarihi: 10.05.2021

Doi: $10.18026 /$ cbayarsos.682772

\section{The Factors Affecting The Patient's Choice of Provider In Health Sector}

\begin{abstract}
Choosing providers in the health sector can be defined as the choice of one of the alternative providers by the patient or their relatives. But, because of the complexity of health services, it is often not easy to choose among providers. Therefore, the aim of this study is to determine the preferences of individuals and the factors that affect their choice. To achieve these objectives, the data set of Life Satisfaction Survey conducted by TUIK in 2016 was used. The choices of individual were examined separately at the level of public and private health institutions and hospitals. As a result of the study, it is determined that public hospitals are more preferred and the individuals are affected by other factors such as satisfaction of health services and proximity of provider as well as their individual and demographic characteristics when they choice provider.
\end{abstract}

Keywords

Health Care Providers

Choice of Hospital

Patient Satisfaction

TUIK

\begin{aligned} About Article \\ \hline Received: 31.01 .2020 \\ Accepted: 10.05 .2021\end{aligned}

Doi: $10.18026 /$ cbayarsos.682772

\footnotetext{
a İletişim Yazarı: birolyetim@hacettepe.edu.tr.

b Arş. Gör. Hacettepe Üniversitesi, İktisadi ve İdari Bilimler Fakültesi, Sağlı Yönetimi Bölümü, ORCID ID: 0000-0002-1294-1874.

c Prof. Dr. Hacettepe Üniversitesi, İktisadi ve İdari Bilimler Fakültesi, Sağlık Yönetimi Bölümü, ORCID ID: 0000-0002-8051-9245.
} 


\section{Giriş}

Özellikle son yıllarda, değişen teknoloji ve hizmet sunumundaki gelişmelerle birlikte sağlık hizmeti sunucuları arasındaki rekabet artmış ve bu rekabetin bir sonucu olarak; hasta memnuniyeti, sağlık kurumlarının nihai hedeflerinden biri haline gelmiştir (Akgün ve Öztürk, 2002). Ancak günümüz hastanelerinde; sadece poliklinik, tanı, tedavi ve ameliyat gibi genel sağlık hizmetleri, hasta memnuniyetini sağlamada ve hizmet sunucu tercihlerini etkilemekte tek başına yeterli değildir. Bu nedenle, birçok sağlık kurumunda, söz konusu temel sağlık hizmetlerinin yanı sıra konfor, bürokratik kolaylıklar ve güler yüzlü sağlık çalışanı gibi farklı türden hizmetler de sunulmaya çalışılmaktadır (Demirer ve Bülbül, 2014).

Hızlı nüfus artışının bir sonucu olarak, sağlık hizmeti sunucularının sayısı ve sundukları sağlık hizmetlerinin çeşitliliği, hem özel sektörde hem de kamu sektöründe ciddi bir artış göstermiştir. Sunucu sayısındaki ve hizmet çeşitliliğindeki bu artışın yanı sıra bireylerin sağlık bilgi düzeylerinde de ciddi bir artış meydana gelmiştir (Karahan, Tarcan ve Yeşilaydın, 2016). Ayrıca 2006 yılında yürürlüğe giren 5510 sayılı Sosyal Sigortalar ve Genel Sağlık Sigortası Kanunu ile hastalar, anlaşmalı özel hastanelerden hizmet alabilme imkânına kavuşmuştur. Bu durum ise bireylerin daha fazla alternatife sahip olmalarını sağlamıştır. Sonuç itibariyle, önceleri seçenekleri çok daha az olan hasta ve yakınları, günümüzde kısmen de olsa karar verici konumuna gelmişlerdir. Ancak tüm bu gelişmelere rağmen, bilgi asimetrisi (Bilgili ve Ecevit, 2008; Cardon ve Hendel, 2001; De Fraja, 2000) ve sağlık hizmetlerinin karmaşık doğası gibi birçok farklı nedenden dolayı, hastalar için sağlık hizmeti sunucusuna karar verebilmek diğer sektörlerde olduğu kadar kolay değildir (Hibbard ve Peters, 2003).

Literatür incelendiğinde; bireylerin sağlık hizmet sunucu tercihlerinin farklı faktörlerden etkilendiğini ortaya koyan çok sayıda çalışma (Abraham, Sick ve Anderson 2011; Campbell, Seymour ve Primrose, 2004; Kinchen, Cooper ve Levine, 2004; Thuan, Lofgren ve Lindholm, 2008) olduğunu görmek mümkündür. Bu faktörlerin bir kısmı bireysel özelliklerdir. Ancak bireylerin sağlık hizmet sunucu tercihlerini etkileyen faktörlerin önemli bir kısmı, hizmet sunum kalitesi, teknik donanım ve uzman sağlık personeli gibi hizmet sunucuları ile ilgili faktörlerdir. $\mathrm{Bu}$ nedenle günümüz dünyasının yoğun rekabet ortamında ayakta kalmak isteyen sağlık yöneticilerinin, hastaların tercihlerinde etkili olan faktörleri belirleyebilmeleri ve bu faktörleri, örgütsel amaçlar doğrultusunda kullanabilmeleri gerekmektedir (Karahan ve diğerleri 2016).

\section{Sağlik Hizmet Sunucu Tercihi}

Sağlık hizmetleri bakımından hizmet sunucu tercihi, hastaların ya da onun bakımından sorumlu olan kişilerin, seçim olanağına sahip oldukları durumlarda, alternatif sağlık hizmeti sunucularından birini tercih etmeleri olarak tanımlanabilir (Tengilimoğlu, 2001). Ancak hizmet sunucuları arasında bir tercih yapabilmek çoğu zaman kolay değildir (Chernew, Scanlon ve Hayward, 1998). Çünkü sağlık hizmetleri kullanımı ve bireylerin hizmet sunucu tercihleri çok farklı faktörlerden etkilenmektedir. Bu faktörlerin bir kısmı hasta ve yakınları ile ilgiliyken bir kısmı ise hizmet sunucuları ile ilişkilidir (Çelik, 2011).

Boscarione ve Stelber, 1982 yılında yaptıkları bir çalışmada; sağlık kurumunun eve yakın olmasının, hekim tavsiyelerinin, sağlık kurumlarındaki uzman hekimlerin, diğer sağlık çalışanlarının ve teknik donanımın, bireylerin hizmet sunucu tercihlerinde etkili olan en önemli faktörler olduğunu tespit etmişlerdir. Yazarlara göre bireyler, bu faktörlerin yanı sıra diğer sağlık kurumlarının hizmet kalitelerine, o kurumlarda tanıdıklarının olup olmamalarına 
ve sunulan hizmetlerin fiyatlarma da dikkat etmektedirler (Boscarione ve Stelbler, 1982). He ise bireylerin tercihlerini etkileyen bu faktörleri; bireylerin bireysel ve demografik özellikleri, değer yargıları ve sağlık kurumlarının temel özellikleri olarak üç grupta ele almıştır. Yazara göre, hastaların sağlık hizmeti sunucu tercihleri bu üç grupta yer alan faktörlerin birbirleriyle karşılıklı etkileşimi sonucunda şekillenmektedir (He, 2011). Ancak bireylerin tercihlerini etkileyen bu faktörlerin önem sırası her bir sağlık hizmeti kullanıcısı için farklı düzeylerde olmaktadır. Özellikle karmaşık müdahaleler gerektiren durumlarda, hasta ve yakınlarının hizmet sunucu tercihlerini etkileyen en önemli faktörler, teknik donanımın varlığ 1 ve çalışan personelin niteliğidir. Ancak acil durumlarda, hizmet sunucularının yakınlığı çok daha önemli bir faktör haline gelmektedir (Şantaş, Kurşun ve Kar, 2016).

Sağlık sektöründe hizmet sunucusu tercihi birçok faktörden etkilenen ve sağlık hizmetlerinin doğası gereği karmaşık bir süreçtir. Mosadeghrad 2014 yılında yaptığı bir çalışmada, hastaların sunucu tercihlerini etkileyen bu faktörleri, 10P (ürün (product), ulaşım (place), ücret (price), fiziki çevre (physical environment), insan (people), süreç (processes), paket (package), performans (performance), imaj (position) ve tavsiye (promotion)) olarak ifade ettiği sağlık hizmetleri piyasasının temel dinamikleri kapsamında açıklamaya çalışmıştır. Yazara göre hasta ve yakınlarının sağlık hizmet sunucu tercihleri bu faktörlerinin karşılıklı etkişiminin bir sonucu olarak şekillenmektedir ve bireylerin içinde bulundukları duruma ve bireysel özelliklerine göre farkl1lık göstermektedir (Mosadeghrad, 2014).

Hasta ve yakınlarının sağlık hizmet sunucu tercihinde önemli bir karar verici olmaya başladığ günümüzde, sağlık hizmetleri pazarında etkin bir rol oynamak isteyen sağlık yöneticilerinin, hasta ve yakınlarının sunucu tercihlerinde etkili olan bu türden faktörleri iyi bir şekilde analiz edebilmeleri (Tengilimoğlu, 2001) ve sektörde rekabet avantajı sağlayabilecek farklı türden stratejiler geliştirebilmeleri gerekmektedir. Bu kapsamda; bu çalışmada, Türkiye' de yaşayan bireylerin, hizmet almak için öncelikli olarak tercih ettikleri sağlık hizmet sunucularının belirlenmesi ve bireylerin bu tercihlerini etkileyen faktörlerin tespit edilmesi amaçlanmıştır.

\section{Yöntem}

\section{Araştırmanın Modeli}

Bu çalışmanın temel amacl; Türkiye'de yaşayan bireylerin sağlık hizmet sunucu tercihlerinin belirlenmesi ve bireylerin söz konusu tercihlerini etkileyen temel faktörlerin tespit edilmesidir. Çalışmanın amaçlarına ulaşabilmek için Türkiye İstatistik Kurumu (TÜİK) tarafından 2016 yılında yapılan Yaşam Memnuniyeti Araştırması (YMA) veri seti kullanılmıştır. YMA'ya katılan bireylerin tercih ettikleri hizmet sunucuları "En son sağlik hizmeti aldığınız sağlık kuruluşu hangisidir?" sorusuna verdikleri cevaplar üzerinden ele alınmıştır. Ancak bu çalışmada, bireylerin hizmet sunucu tercihleri hem sektörel bazda (kamu/özel) hem de hastaneler bazında ayrı ayrı incelenmiştir. Bu nedenle yukarıdaki soruya verilen cevaplardan hareketle iki ayrı değişken oluşturulmuştur. İlk olarak bireylerin bu soruya verdikleri cevaplar kamu sağlık kuruluşları (aile hekimliği, devlet hastanesi ve üniversite hastanesi) ve özel sağlık kuruluşları (özel hastane, özel poliklinik ve özel tıp merkezleri) olmak üzere farklı şekillerde sınıflandırılarak yeniden kodlanmıştır. Yapılan bu yeni sınıflandırmalara kurum doktoru tercihi dâhil edilmemiştir. Hastaneler bazında karşılaştırma yapabilmek için sadece devlet hastanesi, üniversite hastanesi ve özel hastane cevapları dikkate alınmış; bireylerin bu soruya verdikleri diğer cevaplar (aile hekimliği, özel poliklinik, özel tıp merkezi ve kurum doktoru) 
ise kapsam dişında tutularak yeni bir değişken daha oluşturulmuştur. Oluşturulan bu yeni değişkenler bu çalışmanın bağımlı değişkenleri olarak kullanılmıştır.

Bireylerin sağlık hizmeti sunucu tercihlerinde etkili olduğu düşünülen bireysel ve demografik özellikler (cinsiyet, yaş, medeni durum, eğitim durumu, çalışma durumu ve sosyal güvence) ile bireylerin "Bu hastaneyi neden tercih ettiniz?" sorusuna verdikleri cevaplar (zorunluluk, yakınlık, memnuniyet, tavsiye, tanıdık, alışkanlık ve katkı payının düşük olması) bu çalışmanın bağımsız değişkenleri olarak ele alınmıştır. Eğitim düzeyi, çalışma durumu ve sosyal güvenlik türü değişkenleri çalışmanın amacına uygun olacak şekilde yeniden kodlanmış ve analizler bu yeni değişkenler dikkate alınarak yapılmıştır.

$\mathrm{Bu}$ çalışma kapsamında aşağıdaki sorulara cevap aranmaya çalışılmıştır.

Araştırma Sorusu 1: Bireyler en son hangi sağlık kurumundan hizmet almışlardır?

Araştırma Sorusu 2: Bireylerin sağlık hizmeti sunucu tercihleri üzerinde bireysel ve demografik özelliklerinin istatistiksel olarak anlamlı bir etkisi var mıdır?

Araştırma Sorusu 3: Bireylerin sağlık hizmeti sunucu tercihleri üzerinde tercih nedenlerinin istatistiksel olarak anlamlı bir etkisi var mıdır?

\section{Evren ve Örneklem}

Çalışmada, TÜİK tarafından 2016 yılında yapılan YMA veri seti ilgili kurumdan gerekli izinler alınarak kullanılmıştır (Başvuru No: 2016). TÜiK, bu araştırmalarda, iki aşamalı tabakalı örnekleme yöntemi kullanmakta ve ilk aşamada, 100'er haneden oluşan kümeler seçerek her kümeden en az 10'ar haneden oluşan bir örneklem büyüküğü belirlemektedir. İkinci aşamada ise, örnekeleme seçilen tüm hane bireylerine ulaşılmaya çalışmaktadır.

2016 yılında yapılan YMA'da, TÜİK tarafından, toplam 514 küme belirlenmiş ve bu kümelerden hareketle örneklem büyüklüğü 5140 hane olarak hesaplanmıştır. Sonuçta 4526 hanede yaşayan 8981 bireyden veri tooplanmıştır (TÜİK, 2018). Bu çalışmanın kapsamını da TÜIK'in ulaştığı 8981 birey oluşturmaktadır. Ancak YMA'da bazı sorulara verilen cevaplarda eksik veriler bulunmaktadır. Bu nedenle, yapılan analizlerde eksik veriler veri setinden çıkarılmış ve analizler kalan gözlemler dikkate alınarak gerçekleştirilmiştir.

\section{Verilerin Analizi}

YMA veri seti, SPSS 23.0 (Statistical Package for Social Sciences) programı yardımıla analiz edilmiş ve verilerin analizinde tanımlayıcı istatistikler ve regresyon analizinden faydalanılmıştır. Bireylerin sağlık hizmeti sunucu tercihlerini etkileyen faktörleri tespit edebilmek için iki ayrı lojistik regresyon modeli tasarlanmıştır. Birinci modelde tercih edilen sağlık kuruluşu (özel/kamu) bağımlı değişken olarak alınmış ve bireylerin tercihlerini etkileyen faktörleri tespit edebilmek için "Binary Lojistik Regresyon" analizi yapılmıştır. İkinci modelde ise bağımlı değişken olarak bireylerin hastane tercihleri (devlet/üniversite/özel) dikkate alınmıştır. Bu modelde ise "Multinominal Lojistik Regresyon" analizi yapılarak bireylerin hizmet sunucu tercihlerini etkileyen faktörler ortaya konulmaya çalışılmıştır.

\section{Bulgular}

Tablo 1'de 2016 yılında TÜİK tarafından yapılan YMA'ya katılan bireylerin bireysel ve demografik özelliklerine ilişkin tanımlayıcı istatistiklere yer verilmiştir. 
Tablo 1. Katılımcıların Tanımlayıcı İstatistikleri*

\begin{tabular}{lcc}
\hline Değişkenler & Siklık (n) & Yüzde (\%) \\
\hline Erkek & 4035 & 44,9 \\
Kadın & 4946 & 55,1 \\
\hline $18-29$ & 1879 & 20,9 \\
$30-39$ & 1987 & 22,1 \\
$40-49$ & 1744 & 19,4 \\
$50-59$ & 1565 & 17,4 \\
$60+$ & 1806 & 20,1 \\
\hline Bekâr & 1431 & 17,7 \\
Evli & 6666 & 82,3 \\
\hline Eğitim Almamış & 1416 & 15,8 \\
İlköğretim & 4407 & 49,1 \\
Lise & 1812 & 20,2 \\
Üniversite & 1346 & 15,0 \\
\hline Çalışıor & 3779 & 42,1 \\
Çalışmiyor & 5202 & 57,9 \\
\hline Sosyal Güvencesi Olan & 7731 & 86,4 \\
Sosyal Güvencesi Olmayan & 1221 & 13,6 \\
\hline
\end{tabular}

Çalışma kapsamındaki katılımcıların \% 55,1'i kadındır. Ayrıca Tablo 1 incelendiğinde; katılımcıların yarısına yakınının (\% 43,0) 18-39 yaşları arasında yer aldığı görülmektedir. Yaş bakımından gruplar arasında benzer bir dağılım olsa da 50 yaş ve üzerindeki bireyler, katılımcıların üçte birinden fazlasını (\% 37,5) oluşturmaktadır. Ayrıca katılımcıların \% 82,3'ü evlidir. Katılımcıların \% 17,7'si ise bekârdır. İlköğretim mezunları, katılımcıların yaklaşık yarısını oluşturmaktadır. Katılımcıların \% 16'sı ise herhangi bir eğitim almadığını belirtmiştir. Sosyal güvencesi olmayan bireyler ise katılımcıların yaklaşık \% 14'ünü oluşturmaktadır.

Tablo 2. Katılımcıların Sağlık Kuruluşu ve Hastane Tercihleri

\begin{tabular}{lcc}
\hline Değişkenler & S1klık (n) & Yüzde (\%) \\
\hline Sağlık Kuruluşu Tercihi & & \\
Kamu Sağlık Kuruluşları & 6039 & 83,6 \\
Özel Sağlık Kuruluşları & 1188 & 16,4 \\
\hline Hastane Tercihi & & \\
Devlet Hastanesi & 4009 & 73,4 \\
Üniversite Hastanesi & 365 & 6,7 \\
Özel Hastane & 1090 & 19,9 \\
\hline
\end{tabular}

*YMA veri setinde bu değiş̧kenlere ait eksik veriler vardır.

Tablo 2'de bireylerin en son sağlık hizmeti aldıkları hizmet sunucuları verilmiştir. Tablo 2 incelendiğinde, çalışma kapsamındaki bireylerin \% 83,6'sının kamu; \% 16,4'ünün özel sağlık kuruluşlarını tercih ettikleri görülmektedir. Hastane tercihleri incelendiğinde, bireylerin büyük bir çoğunluğunun $(\%$ 73,4) devlet hastanelerini, \% 6,7'sinin ise üniversite hastanelerini tercih ettikleri görülmektedir. Özel hastaneleri tercih edenler, katılımcıların yaklaşık \% 20'sini oluşturmaktadir. 
Tablo 3. Sağlık Kuruluşu Tercih Nedenleri

\begin{tabular}{lcc}
\hline Tercih Nedeni & Sıklık (n) & Yüzde (\%) \\
\hline Yakınlık & 2517 & 34,6 \\
Memnuniyet & 2434 & 33,5 \\
Zorunluluk & 1696 & 23,3 \\
Düşük Katılım Payı & 191 & 2,6 \\
Tanıdık & 155 & 2,1 \\
Tavsiye & 145 & 2,0 \\
Alışkanlık & 128 & 1,8
\end{tabular}

Tablo 3'te bireylerin hizmet aldıkları sağlık hizmet sunucularını tercih etme nedenleri verilmiştir. Katılımcıların \% 34,6'sı evlerine yakın olan hastaneleri tercih ederken \% 33,5'i ise daha önceden almış oldukları sağlık hizmetlerinden memnun kaldıkları sağlık kurumlarını tercih etmişlerdir. Ancak katılımcıların yaklaşık dörtte biri $(\% 23,3)$ bu kurumlardan sağlık hizmeti almaya mecbur kaldıklarını ifade etmişlerdir.

Tablo 4. Kamu ve Özel Sağlık Kuruluşu Tercihini Etkileyen Faktörler*

\begin{tabular}{lcccc}
\hline Değisskenler & B & S.E. & Sig & Exp(B) \\
\hline Erkek & $-0,209$ & 0,085 & 0,014 & 0,811 \\
Kadın & Referans & & & \\
\hline $18-29$ & 0,276 & 0,144 & 0,055 & 1,318 \\
$30-39$ & 0,157 & 0,132 & 0,235 & 1,170 \\
$40-49$ & $-0,067$ & 0,136 & 0,622 & 0,935 \\
$50-59$ & $-0,257$ & 0,138 & 0,062 & 0,773 \\
$60+$ & Ref & & & \\
\hline Bekâr & $-0,170$ & 0,119 & 0,152 & 0,843 \\
Evli & Referans & & & \\
\hline Eğitim Almamış & $-1,111$ & 0,161 & 0,000 & 0,329 \\
İköğretim & $-1,099$ & 0,111 & 0,000 & 0,333 \\
Lise & $-0,657$ & 0,112 & 0,000 & 0,518 \\
Üniversite & Referans & & 0,000 & \\
\hline Çalışıyor & 0,293 & 0,088 & 0,001 & 1,341 \\
Çalışmıor & Referans & & & \\
\hline Sosyal Güvencesi Olan & 0,593 & 0,150 & 0,000 & 1,810 \\
Sosyal Güvencesi Olmayan & Referans & & & \\
\hline Zorunluluk & $-0,061$ & 0,301 & 0,840 & 0,941 \\
Yakınlık & $-0,130$ & 0,295 & 0,659 & 0,878 \\
Memnuniyet & 1,544 & 0,288 & 0,000 & 4,686 \\
Tavsiye & 2,194 & 0,339 & 0,000 & 8,972 \\
Tanıdık & 1,897 & 0,343 & 0,000 & 6,667 \\
Alışkanlık & 0,264 & 0,412 & 0,522 & 1,302 \\
Düşük Katılım Payı & Referans & & 0,000 & \\
\hline Constant & $-1,822$ & 0,105 & 0,000 & 0,162 \\
\hline Cox ve Snen & & & &
\end{tabular}

Cox ve Snell $R^{2}: 0,121$

Nagelkerke $R^{2}:$ 0,205

* 0: Kamu Sağlık Kuruluşları; 1: Özel Sağlık Kuruluşlar 
Bireylerin kamu ve özel sağlık kuruluşu tercihlerini etkileyen faktörleri tespit edebilmek için "Binary Lojistik Regresyon" analizi yapılmış ve elde edilen sonuçlar Tablo 4' te verilmiştir. Bu modelde katılımcıların bireysel ve demografik özelliklerinin yanı sıra sağlık hizmeti sunucusu tercih etme nedenleri bağımsız değişken olarak kullanılmıştır. Model, Nagelkerke testine göre, bireylerin kamu ve özel sağlık kuruluşu tercihlerindeki toplam varyansın yaklaşık \% 20'sini açıklamaktadır. Model ayrıca bireylerin sunucu tercihlerinin yaklaşık \% 84'ünü doğru tahmin edebilmektedir.

Tablo 4 incelendiğinde; medeni durum ve yaş dışında modele dâhil edilen diğer tüm değişkenlerin bireylerin hizmet sunucu tercihlerini etkilediği görülmektedir $(p<0,05)$. Kadınlar ile kıyaslandığında, erkekler sağlık hizmeti almak için kamu sağlık kuruluşlarını daha çok tercih etmektedir. Ayrıca üniversite mezunlarının özel sağlık kuruluşlarını diğerlerine kıyasla daha çok tercih ettikleri görülmektedir. Dahası eğitim düzeyinin artması ile birlikte bireylerin özel sağlık kuruluşlarından hizmet almaya başladığı söylenebilir.

Bireylerin hizmet sunucu tercihlerini etkileyen bireysel ve demografik faktörlerinden biri de çalışma durumudur. Bu çalışmada ayrıca çalışan bireylerin özel sağlık kuruluşlarını daha çok tercih ettikleri tespit edilmiştir. Benzer şekilde sosyal güvencesi olan bireyler de kamudan ziyade özel hizmet sunucularından hizmet almaktadır $(\mathrm{p}<0,05)$.

Bireylerin hizmet sunucu tercihleri üzerinde bireysel ve demografik özelliklerinin yanı sıra zorunluluk, yakınlık ve alışkanlık dışında kalan diğer tercih nedenlerinin de etkili olduğu tespit edilmiştir $(p<0,05)$. Tablo 4 incelendiğinde; daha önceden almış oldukları sağlık hizmetinden memnun olan bireylerin özel sağlık kuruluşlarını daha çok tercih ettikleri görülmektedir. Ayrıca yakın çevrelerinin tavsiyelerini dikkate alanlar ile özel sağlık kuruluşlarında tanıdığı olan bireyler de benzer şekilde özel sağlık kuruluşlarını daha çok tercih etmektedirler. 
Tablo 5. Bireylerin Hastane Tercihlerini Etkileyen Faktörler

\begin{tabular}{|c|c|c|c|c|c|c|c|c|c|c|c|c|}
\hline \multirow[b]{2}{*}{ Değişkenler } & \multirow[b]{2}{*}{ B } & \multicolumn{3}{|c|}{ DH-ÜH* } & \multicolumn{5}{|c|}{ DH-ÖH ${ }^{* *}$} & \multicolumn{3}{|c|}{ ÜH-ÖH*** } \\
\hline & & S.E. & Sig & $\operatorname{Exp}(B)$ & B & S.E. & Sig & $\operatorname{Exp}(B)$ & B & S.E. & Sig & $\operatorname{Exp}(B)$ \\
\hline Intercept & $-3,742$ & 0,792 & 0,000 & & $-1,922$ & 0,365 & 0,000 & & 1,820 & 0,847 & 0,032 & \\
\hline $18-29$ & $-0,707$ & 0,245 & 0,004 & 0,493 & 0,227 & 0,155 & 0,143 & 1,255 & 0,935 & 0,266 & 0,000 & 2,547 \\
\hline $30-39$ & $-0,335$ & 0,211 & 0,112 & 0,715 & 0,070 & 0,142 & 0,621 & 1,073 & 0,405 & 0,231 & 0,080 & 1,500 \\
\hline $40-49$ & $-0,120$ & 0,208 & 0,565 & 0,887 & $-0,117$ & 0,147 & 0,425 & 0,889 & 0,002 & 0,232 & 0,992 & 1,002 \\
\hline $50-59$ & $-0,023$ & 0,195 & 0,908 & 0,978 & $-0,264$ & 0,148 & 0,074 & 0,768 & $-0,241$ & 0,223 & 0,279 & 0,786 \\
\hline $60+$ & Referans & & & & Referans & & & & Referans & & & \\
\hline Erkek & $-0,124$ & 0,137 & 0,366 & 0,883 & $-0,211$ & 0,092 & 0,022 & 0,810 & $-0,087$ & 0,150 & 0,564 & 0,917 \\
\hline Kadın & Ref & & & & Ref & & & & Ref & & & \\
\hline Bekâr & 0,203 & 0,201 & 0,314 & 1,225 & $-0,303$ & 0,130 & 0,019 & 0,738 & $-0,506$ & 0,218 & 0,020 & 0,603 \\
\hline Evli & Referans & & & & Referans & & & & Referans & & & \\
\hline Ĕ̆itim Almamış & $-1,387$ & 0,269 & 0,000 & 0,250 & $-1,508$ & 0,176 & 0,000 & 0,221 & $-0,121$ & 0,291 & 0,678 & 0,866 \\
\hline İlköğreim & $-1,050$ & 0,195 & 0,000 & 0,350 & $-1,359$ & 0,125 & 0,000 & 0,257 & $-0,309$ & 0,203 & 0,128 & 0,734 \\
\hline Lise & $-0,480$ & 0,199 & 0,016 & 0,619 & $-0,830$ & 0,128 & 0,000 & 0,436 & $-0,350$ & 0,206 & 0,089 & 0,705 \\
\hline Üniversite & Referans & & & & Referans & & & & Referans & & & \\
\hline Çalışıyor & $-0,212$ & 0,146 & 0,145 & 0,809 & 0,204 & 0,096 & 0,033 & 1,226 & 0,416 & 0,159 & 0,009 & 1,517 \\
\hline Çalışmıyor & Referans & & & & Referans & & & & Referans & & & \\
\hline Sos. Güv. Olan & 0,688 & 0,241 & 0,004 & 1,990 & 0,720 & 0,160 & 0,000 & 2,055 & 0,033 & 0,277 & 0,906 & 1,033 \\
\hline Sos. Güv. Olmayan & Referans & & & & Referans & & & & Referans & & & \\
\hline Zorunluluk & 1,648 & 0,724 & 0,023 & 5,195 & $-0,015$ & 0,307 & 0,960 & 0,985 & $-1,663$ & 0,774 & 0,032 & 0,190 \\
\hline Yakınlık & 1,397 & 0,727 & 0,055 & 4,041 & 0,371 & 0,301 & 0,218 & 1,449 & $-1,025$ & 0,774 & 0,185 & 0,359 \\
\hline Memnuniyet & 2,308 & 0,719 & 0,001 & 10,054 & 1,752 & 0,292 & 0,000 & 5,765 & $-0,566$ & 0,763 & 0,466 & 0,573 \\
\hline Tavsiye & 3,146 & 0,770 & 0,000 & 23,238 & 2,393 & 0,353 & 0,000 & 10,941 & $-0,753$ & 0,811 & 0,353 & 0,471 \\
\hline Tanıdık & 3,200 & 0,767 & 0,000 & 24,538 & 2,253 & 0,360 & 0,000 & 9,512 & $-0,948$ & 0,809 & 0,241 & 0,388 \\
\hline Alışkanlık & 1,353 & 0,850 & 0,112 & 3,869 & 0,204 & 0,435 & 0,638 & 1,227 & $-1,149$ & 0,931 & 0,217 & 0,317 \\
\hline Düşük Katılım Payı & Referans & & & & Referans & & & & Referans & & & \\
\hline
\end{tabular}

*0:DH, 1: $\ddot{U} H,{ }^{* *} 0: D H, 1: \ddot{O H},{ }^{* * *} 0: \ddot{U} H, 1: O ̈ H$

DH: Devlet Hastanesi; ÜH: Üniversite Hastanesi; ÖH: Özel Hastane 
Tablo 5 'te ise bireylerin hizmet sunucu tercihlerini etkileyen faktörleri tespit edebilmek için yapılan "Multinominal Lojistik Regresyon" analizi sonuçları verilmiştir. Bu modelde bireysel ve demografik özellikler ile bireylerin sağlık hizmet sunucusu tercih nedenleri bağımsız değişken olarak kullanılmıştır. Model, Nagelkerke testine göre, bireylerin sunucu tercihlerindeki toplam varyansın yaklaşık \% 20'sini açıklamaktadır. Ayrıca bu model bireylerin hizmet sunucu tercihlerinin \% 74,6'sını doğru tahmin edebilmektedir.

Tablo 5 incelendiğinde; bireylerin sağlık hizmeti sunucusu tercihlerinin bireysel ve demografik özelliklerinden etkilendiği görülmektedir $(p<0,05)$. Özel hastaneler ile kıyaslandığında erkekler devlet hastanelerini daha çok tercih etmektedirler. Ancak devlet hastaneleri ile üniversite hastaneleri ve üniversite hastaneleri ile özel hastaneler karşılaştırıldığında cinsiyet ile bireylerin hizmet sunucu tercihleri arasında istatistiksel olarak herhangi bir ilişki tespit edilememiştir $(p>0,05)$.

Üniversite hastaneleri ile karşılaştırıldığında, 18-29 yaş aralığında yer alan bireylerin devlet hastanelerini; özel ve üniversite hastaneleri kıyaslandığında ise özel hastaneleri daha çok tercih ettikleri görülmektedir. 60 yaş ve üzerindeki bireyler daha çok üniversite hastanelerini tercih etmektedirler. Ancak devlet ve üniversite hastaneleri bakımından bireylerin yaşları ile sunucu tercihleri arasında istatistiksel olarak herhangi bir ilişki tespit edilememiştir $(p>0,05)$.

Bireylerin hastane tercihleri medeni durumlarından da etkilenmektedir $(p<0,05)$. Zira özel hastaneler kıyaslandığında; bekâr bireylerin devlet hastanelerini daha çok tercih ettikleri görülmektedir. Evli bireyler ise kamu hastanelerinden ziyade özel hastaneleri daha çok tercih etmektedirler.

Özel hastaneler ile üniversite hastaneleri karşılaştırıldığında eğitim durumu ile bireylerin tercihleri arasında herhangi bir ilişki tespit edilememiş $(p>0,05)$ olsa da devlet ve üniversite hastaneleri kıyaslandığında; üniversite mezunu bireylerin özel hastaneleri daha çok tercih ettikleri görülmektedir. Ayrıca özel hastaneler ile devlet hastaneleri karşılaştırıldığında da benzer sonuçlara ulaşılmıştır.

Bireylerin sağlık hizmeti sunucu tercihlerini çalışma durumları ve sosyal güvenceleri de etkilemektedir $(\mathrm{p}<0,05)$. Zira devlet hastaneleri ile karşılaştırıldığında çalışan bireylerin daha çok özel hastaneleri tercih ettikleri görülmektedir. Ayrıca üniversite hastaneleri ile özel hastaneler karşılaştırıldığında da benzer sonuçlara ulaşılmaktadır. Öte yandan bireylerin sosyal güvence durumlarına göre tercihleri incelendiğinde ise; devlet ve üniversite hastaneleri karşılaştırıldığında; sosyal güvencesi olmayan bireylerin devlet hastanelerini daha çok tercih ettikleri görülmektedir. Devlet hastaneleri ile özel hastaneler karşılaştırıldığında, sosyal güvencesi olan bireyler daha çok özel hastaneleri tercih etmektedir.

Devlet hastaneleri kıyaslandığında; zorunluluk, memnuniyet, yakın çevrenin tavsiyesi ve tanıdıkların varlığı bireylerin üniversite hastanelerini tercih etmelerinde etkili olan en önemli faktörler arasındadır. Devlet hastaneleri ile özel hastaneler karşılaştırıldığında ise; memnuniyetin, sağlık kurumunun tavsiye edilmiş olmasının ve tanıdık birinin varlığının özel hastanelerin daha çok tercih edilmesinde etkili olduğu görülmektedir. Son olarak özel hastaneler karşılaştırıldığında; zorunluluk üniversite hastanelerinin tercih edilmesinde etkili olan en faktörlerden biridir $(p<0,05)$. 


\section{Tartışma, Sonuç ve Öneriler}

Bu çalışmanın temel amacı, Türkiye' de yaşayan bireylerin hizmet almak için tercih ettikleri sağlık hizmet sunucularının belirlenmesi ve bireylerin bu tercihlerini etkileyen faktörlerin tespit edilmesidir. Araştırmanın bu amacı doğrultusunda 2016 yılında TÜİK tarafından yapılan YMA veri seti kullanılmış ve çalışma kapsamındaki bireylerin sunucu tercihleri hem kamu ve özel sağlık kuruluşları bakımından hem de özel, devlet ve üniversite hastaneleri bakımindan incelenmiştir.

Çalışma sonucunda; yaş, cinsiyet, medeni durum ve eğitim düzeyi gibi bireysel ve demografik faktörlerin bireylerin sağllk hizmet sunucu tercihlerini etkilediği tespit edilmiştir $(p<0,05)$. Çalışma sonucunda; kadınların, evlilerin, üniversite mezunlarının, çalışan ve sosyal güvencesi olan bireylerin, özel sağlık kuruluşlarını daha çok tercih ettikleri görülmektedir. Bu durumun artan eğitim ve gelir düzeyi ile birlikte bireylerin ekonomik olarak çok daha geniş imkanlara sahip olmalarından kaynaklandığı düşünülmektedir. Çalışan ve sosyal güvencesi olan bireylerin özel hastaneleri daha çok tercih ettikleri etmelerinin nedenlerinden biri de bazı işverenlerin çalışanlarına tamamlayacı olarak özel sağlık sigorta paketleri sağlamaları olabilir. $\mathrm{Bu}$ durum, özel hastanelerin çok daha fazla tercih edilmesine neden olabilir. Ayrıca evlilik ile birlikte ihtiyaç duyulan sağlık hizmetlerinin farklılaşması da evli bireylerin özellik de kadınların özel hastaneleri daha çok tercih etmelerine neden olmuş olabilir. Öte yandan; hastane özelinde kıyaslandığında ise yaşlı bireylerin gençlere kıyasla üniversite hastanelerini daha çok tercih ettikleri görülmektedir. Bu durumun ise; yaşlanmayla beraber artan kronik hastalıklar nedeniyle yaşlı bireylerin daha karmaşık sağlık hizmetlerine ihtiyaç duymalarından kaynaklandığ 1 düşünülmektedir.

Literatür incelendiğinde bu çalışma bulgularını destekler nitelikte çok sayıda çalışma olduğu da görülmektedir. Örneğin Al- Doghaither ve arkadaşları 2003 yılında yaptıkları bir çalışmada, Riyad'da yaşayan bireylerin sağlık kurumu tercihlerini incelemişler ve çalışma sonucunda; bireysel ve demografik faktörlerin bireylerin sağllk hizmet sunucu tercihlerini etkilediklerini tespit etmişlerdir. Yazarlar çalışmalarında, eğitim düzeyi daha yüksek olan ve daha yüksek gelir düzeyine sahip olan bireylerin özel sağlık kurumlarını daha çok tercih ettiklerini raporlamışlardır. Ancak söz konusu çalışmada, medeni durum ile hizmet sunucu tercihleri arasında istatistiksel olarak anlamlı herhangi bir ilişki tespit edememişlerdir (AlDoghaither, Abdelrhman ve Saeed, 2003). Andaleeb de 2000 yılında yaptığ bireylerin hizmet sunucu tercihlerinin iletişim, hasta güvenliği ve duyarlılık gibi hizmet sunucu özelindeki birtakım faktörlerin yanı sıra gelir durumu ve eğitim düzeyi gibi bireysel ve demografik faktörlerden de etkilendiğini ortaya koymuştur. Yazar çalışma sonucunda, eğitim ve gelir düzeyi daha yüksek olan bireylerin kamu sağlık kurumları ile kıyaslandığında özel sağlık kurumlarını daha çok tercih ettiklerini tespit etmiştir (Andaleeb, 2000). Rana ve diğerleri de 2020 yılında yaptıkları bir çalışmada benzer sonuçlara ulaşmıştır. Yazarlar çalışma sonucunda, eğitim düzeyi ve gelir düzeyinin artması ile birlikte bireylerin daha çok özel sağlık kurumlarını tercih ettiklerini tespit etmişlerdir. Yazarlar ayrıca, genç bireylerin kamu sağlık kurumlarını daha çok tercih ettiklerini de raporlamışlardır (Rana, Alam ve Gow, 2020).

Bu çalışmada ayrıca, bireylerin kamu ve özel sağlık kuruluşu tercihleri üzerinde bireysel ve demografik özelliklerinin yanı sıra zorunluluk, yakınlık, tanıdık ve memnuniyet gibi doğrudan hizmet sunucuları ile ilgili birtakım faktörlerin de etkili olduğu tespit edilmiştir $(p<0,05)$. Bu kapsamda; Türkiye' de yaşayan bireyler; kendilerine çok daha yakın olan sağlık kurumlarını öncelikli olarak tercih etmektedirler. Yakınlığın hemen ardından ise sağlık 
kurumunda daha önceden sunulan hizmetten memnuniyet düzeyi ve zorunluluk gibi bazı faktörler gelmektedir. Birçok çalışma da bu bulguyu destekler niteliktedir. Örneğin; Mack ve arkadaşları 1995 yılında yaptıkları çalışmalarında, memnuniyet düzeyi ile hizmet sunucu tercihleri arasında güçlü ve pozitif bir ilişki olduğunu tespit etmişler ve memnuniyet düzeyinin artması ile birlikte bireylerin söz konusu sağlık hizmet sunucusunu daha çok tercih etme eğiliminde olduklarını ileri sürmüşlerdir (Mack, File ve Horwitz, 1995). Swan ve arkadaşları da 1985 yılında yaptıkları bir çalışmada, memnuniyetin hizmet sunucu tercihini etkileyen önemli unsurlardan biri olduğunu bulgulamışlardır (Swan, Sawyer ve Van Matre, 1985). Öte yandan Boscarino ve Stelber (1982), Robertson ve Dixon (2008) ve Wolinsky ve Kurz (1984) ise, farklı yıllarda yaptıkları çalışmalarında sağlık hizmeti sunucularının yakınlık düzeylerinin, tercih edilmelerinde etkili olan unsurlar arasında yer aldığını tespit etmişlerdir (Boscarino ve Stelber, 1982; Robertson ve Dixon, 2008; Wolinsky ve Kurz, 1984).

Bireylerin hizmet sunucu tercihleri hastaneler düzeyinde incelendiğinde de benzer sonuçlara ulaşılmıştır. Kadınların ve üniversite mezunlarının daha çok özel hastaneleri tercih ettikleri görülmektedir. Benzer şekilde çalışan ve sosyal güvencesi olan bireyler de özel hastaneleri daha çok tercih etmektedirler. Ancak yaşlı bireylerin devlet ve özel hastanelerden ziyade üniversite hastanelerini daha çok tercih ettikleri söylenebilir. Bu durumun temel nedeni yaşlı bireylerde daha çok kronik hastalıkların olması olabilir.

Hastane tercihinde etkili olan faktörlerden biri de zorunluluktur. Bireylerin önemli bir kısmının başka seçeneği olmadığı için üniversite hastanelerini tercih ettikleri tespit edilmiştir. Ancak özel hastanelerin tercih edilmesinde etkili olan faktörlerin başında memnuniyet, tavsiye ve tanıdıklar gelmektedir.

Bu kapsamda;

a. Diğer hastaneler ile kıyaslandığında devlet hastanelerinin tercih edilmesinde memnuniyetten ziyade yakınlık ve zorunluluk gibi nedenlerin daha etkili olduğu görülmektedir. Devlet hastanelerinde memnuniyet konusundaki eksikliklerin bir an önce tespit edilip giderilmesi ve sunulan sağlık hizmetlerinin iyileştirilmesi gerekmektedir. Bu amaçla özel hastanelerin neleri daha iyi yaptığı araştırılabilir.

b. Özel hastane tercihlerinde tanıdık ve tavsiye gibi faktörlerin ön plana çıkmasında bireylerde özel hastanelere karşı bir önyargının olmasından kaynaklanabilir. Hasta ve yakınlarının özel hastanelere gitmeden önce doğru kişiden hizmet aldıklarından ve ödeyecekleri paranın tam karşılığını almak istediklerinden dolayı tavsiye aldıkları ya da özel hastanelere olan gücen düzeyinin düşük olabileceği düşünülmektedir. Eğer özel hastanelere yönelik olası önyargılar ortadan kaldırılabilir ve hastalarda güven duygusu oluşturulabilirse özel hastaneler daha çok tercih edilebilir.

c. Çalışma kapsamındaki bireylerin önemli bir kısmı tercihten öte zorunluluklardan dolayı hizmet aldıkları sağlık kurumlarına gittiklerini bildirmişlerdir. Ancak veri setinde zorunluluklar ile ilgili detaylı bir bilgi olmadığı için sonraki çalışmalarda bireylerin ne tür zorluklarla karşılaştıklarının tespit edilmesi önerilir. Böylelikle sorunları ortadan kaldırmaya yönelik çözüm önerileri geliştirilebilir.

d. Bireylerin özel hastaneleri tercih etmelerinde hizmet kalitelerinin yanı sıra tanıdık ve tavsiye de etkilidir. Bu durumun bireylerin özel hastanelere karşı bir güven sorunu 
yaşamalarından kaynaklandığı düşünülmektedir. Dolayısıyla hasta ve yakınlarında güven duygusunun oluşturulması özel hastanelerin daha fazla tercih edilmesini sağlayabilir. Bu kapsamda; özel hastanelerin halkla ilişkiler çalışmalarına önem vermeleri ve kurumlarını daha geniş kitlelere tanıtabilecek stratejiler geliştirmeleri önerilir.

\section{Kaynakça}

Abraham, J., Sick, B., Anderson, J., Berg, A., Dehmer, C., and Tufano, A. J. (2011). Selecting a provider: what factors influence patients' decision making? Journal of Healtcare Management, 56(2), 99-116.

Akgün, H., ve Öztürk, A. (2002). Sağlık hizmetlerinde kalite ve hasta tatmini. Modern Hastane Yönetimi. 6(2).

Al-Doghaither, A., Abdelrhman, B., Saeed, A. W., and Magzoub, M. (2003). Factors influencing patient choice of hospitals in Riyadh, The Journal of The Royal Society for the Promotion of Health. 123(2), 105-109.

Andaleeb, S. S. (2000). Public and private hospitals in Bangladesh: service quality and predictors of hospital choice. Health Policy and Planning. 15(1), 95-102.

Bilgili, E., ve Ecevit, E. (2008). Sağlık hizmetleri piyasasında asimetrik bilgiye bağlı problemler ve çözüm önerileri. Hacettepe Să̆lık İdaresi Dergisi. 11(2).

Boscarino, J., ve Stelber, S. R. (1982). Hospital shopping and consumer choice. Journal of Health Care Marketing. 2(2), 15-23.

Campbell, S. E., Seymour, D. G., and Primrose, W. R. (2004). A systematic literature review of factors affecting outcome in older medical patients admitted to hospital. Age and Ageing. 33(2), 110-115.

Cardon, J. H., and Hendel, I. J. (2001). Asymmetric information in health insurance: evidence from the national medical expenditure survey. Journal of Economics. 32(3), 408-427.

Çelik, Y. (2011). Să̆lık Ekonomisi. Ankara: Siyasal Kitabevi.

Chernew, M., Scanlon, D., and Hayward, R. (1998). Insurance type and choice of hospital for coronary artery bypass graft surgery. Health Services Research. 33(3), 447-466.

De Fraja, G. (2000). Contracts for health care and asymmetric information. Journal of Health Economics, 19(5), 663-677.

Demirer, Ö., ve Bülbül, H. (2014). Kamu ve özel hastanelerde hizmet kalitesi, hasta tatmini ve tercihi arasındaki ilişki: karşılaştırmalı bir analiz. Amme İdaresi Dergisi. 47(2), 95-119.

He, X. (2011). Factors affecting rural kentucky patients hospital choice and bypass behavior. University of Kentucky Master's Theses.

Hibbard, J. H., and Peters, E. (2003). Supporting informed consumer health care decisions: data presentation approaches that facilitate the use of information in choice. Annual Review of Public Health. 24(1), 413-433. 
Karahan, A., Tarcan, G. Y., Yeşilaydın, G. T., ve Tarcan, M. (2016). Hastane tercihlerini etkileyen faktörler: öğrenci bakış açısıyla bir değerlendirme. Sosyal Bilimler Dergisi. 3(9), 298-313.

Kinchen, K. S., Cooper, L. A., Levine, D., Wang, N. Y., and Powe, N. R. (2004). Referral of patients to specialists: factors affecting choice of specialist by primary care physicians. The Annals of Family Medicine, 2(3), 245-252.

Mack, J. L., File, K. M., Horwitz, J. E., ve Prince, R. A. J. H. c. m. r. (1995). The effect of urgency on patient satisfaction and future emergency department choice. Health Care Management Review. 20(2), 7-15.

Mohammad Mosadeghrad, A. (2014). Patient choice of a hospital: implications for health policy and management. International Journal of Health Care Quality Assurance. 27(2), 152-164.

Rana, R. H., Alam, K., \& Gow, J. (2020). Selection of private or public hospital care: examining the care-seeking behaviour of patients with private health insurance. BMC health services research, 20, 1-17.

Robertson, R., ve Dixon, A. (2008). Patient choice in general practice: the implications of patient satisfaction surveys. Journal of Health Services Research ve Policy. 13(2), 67-72.

Şantaş, F., Kurşun, A., ve Kar, A. (2016). Hastane Tercihine Etki Eden Faktörler: Sağlık Hizmetleri Pazarlaması Perspektifinden Alan Araştırması. Hacettepe Sağlık İdaresi Dergisi, 19(1), 17-33.

Swan, J. E., Sawyer, J. C., Van Matre, J. G., ve McGee, G. W. J. J. o. h. c. m. (1985). Deepening the understanding of hospital patient satisfaction: fulfillment and equity effects. Journal of Health Care Marketing. 5(3), 7-18.

Tengilimoğlu, D. (2001). Hastane seçimine etkili olan faktörler: bir alan uygulaması. İktisadi ve İdari Bilimler Fakültesi Dergisi, 3(1), 1-13.

Thuan, N. T. B., Lofgren, C., Lindholm, L., ve Chuc, N. T. K. (2008). Choice of healthcare provider following reform in Vietnam. BMC Health Services Research. 8(1), 162.

TÜIK (2018). Yaşam Memnuniyeti Araştırmaları, http://tuikweb.tuik.gov.tr/MicroVeri/YMA 2016/index.html. Erişim Tarihi: 12.12.2019.

Wolinsky, F. D., ve Kurz, R. S. (1984). How the public chooses and views hospitals. Hospital ve Health Services Administration. 29(6), 58-67.

5510 sayılı sosyal sigortalar ve genel sağlık sigortası kanunu (2006). Resmi Gazete. Yayım Tarihi: 16.06.2006. Say1s1: 26200. Numarasi: 5510.

https://www.mevzuat.gov.tr/MevzuatMetin/1.5.5510.pdf. Erişim Tarihi: 15.12.2019. 